\title{
Kualitas Semen Cair Kambing Boer selama Penyimpanan Suhu Ruang dengan Penambahan Ekstrak Daun Kemangi (Ocimum sanctum)
}

\section{(Semen Quality of Goat Boer during Storage at Room Temperature with Addition of Basil Leaf Extract (Ocimum sanctum))}

\author{
Putri $\mathrm{RF}^{1}$, Hermawan $\mathrm{DH}^{2}$, Suyadi ${ }^{1}$ \\ ${ }^{1}$ Riset Group Genomics and Proteomics Fakultas Peternakan Universitas Brawijaya \\ ${ }^{2}$ Mahasiswa Sarjana Fakultas Peternakan Universitas Brawijaya \\ suyadi@ub.ac.id
}

\begin{abstract}
Spermatoza will undergo metabolism that produced lipid peroxide during storage. Lipid peroxides that reacted with free radicals would increase Reactive Oxygen Species (ROS) that caused sperm quality decreasing during storage. The aim of this experiment was to study the effect of basil leaf extract on semen quality of Boer Goat diluted with Tris egg yolk and stored at room temperature. The materials used were 4 Boer goats aged 4 to 5 years old. The treatments were the addition of basil leaf extract at the level of $0 \%(\mathrm{P} 0), 1 \%(\mathrm{P} 1), 2 \%(\mathrm{P} 2)$ and 3\% (P3). Diluted semen were stored at room temperature and observed at hours $0,1,2$ and 3. The experiment was arranged in a completely randomized design with 4 treatments and 10 repetitions; if there was a difference, it was followed by Duncan's Multiple Range Test. The result showed that there were no significant difference $(\mathrm{P}>0.05)$ on sperm motility and viablity, but there was significant different $(\mathrm{P}<0.05)$ on sperm abnormality by adding basil leaf extract. The lowest percentage of abnormalities at the 0 hour was in P3, meanwhile at 2 and 3 hours of storage, P1, P2, P3 had lower abnomalities than that of control treatment. In conclusion that addition of basil leaf extract (Ocimum sanctum) to the diluent didnot give any effect on the individual motility and viability of Boer goat semen but could reduce abnormalities during room temperature storage.
\end{abstract}

Key words: Boer goat, basil leaf extract, sperm, motility, viablity, abnormality

\begin{abstract}
ABSTRAK
Selama masa penyimpanan, spermatozoa akan mengalami metabolisme yang menghasilkan peroksida lipid, yang apabila bereaksi dengan radikal bebas akan meningkatkan Reactive Oxygen Species (ROS) dan berakibat pada turunnya kualitas sperma selama penyimpanan. Penelitian ini bertujuan untuk mempelajari pengaruh penambahan ekstrak daun kemangi terhadap kualitas spermatozoa yang diencerkan oleh pengencer Tris kuning telur dan disimpan pada suhu ruang. Materi penelitian yang digunakan adalah 4 ekor pejantan kambing Boer berumur 4-5 tahun dengan bobot badan rata-rata $50 \mathrm{~kg}$. Perlakuan dalam penelitian ini adalah penambahan ekstrak daun kemangi sebesar 0\% (P0), 1\% (P1), 2\% (P2) dan 3\% (P3). Semen yang telah diencerkan disimpan dalam suhu ruang dan diamati kualitas pada jam ke 0 , 1, 2 dan 3. Variabel yang diamati adalah motilitas individu, viabilitas dan abnormalitas. Rancangan percobaan yang digunakan adalah Racangan Acak Lengkap, apabila terdapat perbedaan dilanjutkan dengan Uji Jarak Berganda Duncan. Hasil penelitian menunjukkan bahwa pemberian ekstrak daun kemangi tidak berpengaruh $(\mathrm{P}>0,05)$ terhadap motilitas individu dan viabilitas, namun berpengaruh $(\mathrm{P}<0,05)$ terhadap abnormalits spermatozoa
\end{abstract}


kambing Boer selama penyimpanan suhu ruang. Nilai motilitas dan viabilitas terbaik dihasilkan pada P3 dengan penambahan 3\% ekstrak daun kemangi. Persentase abnormalitas

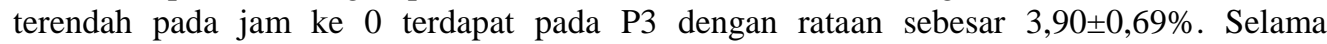
penyimpanan jam ke 2 dan ke 3, perlakuan P1, P2 dan P3 memiliki persentase abnormalitas yang lebih rendah daripada kontrol. Disimpulkan bahwa penambahan ekstrak daun kemangi (Ocimum sanctum) ke dalam pengencer belum mampu memberikan pengaruh terhadap motilitas individu dan viabilitas semen kambing Boer namun mampu mengurangi abnormalitas selama penyimpanan suhu ruang.

Kata kunci: Kambing Boer, ekstrak daun kemangi, motilitas, viabilitas, abnormalitas, spermatozoa

\section{PENDAHULUAN}

Inseminasi Buatan (IB) merupakan teknologi di bidang reproduksi yang memiliki peranan penting dalam peningkatan mutu genetik dan produksi ternak. Kualitas dan kuatintas semen adalah salah satu faktor penentu keberhasilan IB. Pada umumnya, semen yang digunakan dalam IB berupa semen beku yang memiliki kelemahan yaitu persentase kematian spermatozoa mencapai $30 \%$. Ketersediaan nitrogen cair yang relatif mahal juga menjadi penghambat penggunaan semen beku. Penggunaan semen cair menjadi alternatif pengganti semen beku. Proses IB menggunakan semen cair memerlukan pengencer karena semen yang disimpan di suhu ruang akan mengalami metabolisme yang dapat menyebabkan kualitas semen menurun.

Pengencer berfungsi sebagai sumber energi sperma selama masa penyimpanan dan berperan sebagai kontrol $\mathrm{pH}$ serta mempertahankan tekanan osmosis spermatozoa. Bahan yang dapat digunakan sebagai pengencer salah satunya adalah Tris Kuning Telur. Tris Kuning Telur merupakan pengencer yang terdiri dari asam sitrat, rafinosa, fruktosa, lakstosa, penicylin, streptomycin, aquabidest dan kuning telur. Pengencer tris memiliki sifat buffer yang baik, kandungan glukosa dapat berguna sebagai sumber energi dan kandungan kuning telur berguna sebagai sumber asam amino bagi spermatozoa (Setiono et al. 2015). Selama proses penyimpanan semen akan mengalami proses metabolisme. Peroksida lipid merupakan salah satu zat yang dihasilkan selama proses metabolisme. Reaksi peroksida lipid dengan radikal bebas dapat menyebabkan penurunan kualitas spermatozoa. Oksidasi lipid (lipid peroksidase) pada membran spermatozoa menghasilkan senyawa malondialdehyde (MDA), yang bersifat toksik pada sel sehingga menyebabkan kerusakan membran spermatozoa dan menyebabkan penurunan integritas membran spermatozoa, sehingga menyebabkan penurunan kualitas sperma (Hayati et al. 2006). Hal ini dapat ditekan melalui penambahan antioksidan kedalam pengencer semen. Flavonoid merupakan salah satu antioksidan yang mampu menangkal radikal bebas. Salah satu tanaman yang menangandung flavonoid adalah kemangi (Ocimum sanctum). Kemangi memiliki kandungan antioksidan alami berupa senyawa fenolik (tokoferol, flavonoid, asam fenolat), senyawa nitrogen (alkaloid, turunan klorofil, asam amino dan amina) dan beta karoten. Diantara senyawa-senyawa tersebut, yang berpengaruh terhadap fertilitas adalah flavonoid, alkaloid dan tannin (Kusuma 2010). Berdasarkan permasalahan tersebut, maka perlu dilakukan penelitian tentang pengaruh penambahan ekstrak daun kemangi (Ocimum sanctum) dalam pengencer terhadap kualitas semen kambing Boer selama pennyimpanan suhu ruang. 


\section{MATERI DAN METODE}

\section{Lokasi dan waktu penelitian}

Penelitian dilakukan pada bulan Desember 2018 hingga Februari 2019. Penampungan dan pengujian kualitas semen segar kambing Boer dilakukan di Laboratorium Lapang Sumber Sekar Fakultas Peternakan Universitas Brawijaya Malang.

\section{Materi penelitian}

Materi penelitian ini menggunakan semen yang ditampung dari 4 ekor pejantan kambing Boer yang berumur 4-5 tahun dengan bobot badan rata-rata $50 \mathrm{~kg}$ yang dipelihara di Laboratorium Lapang Sumber Sekar Fakultas Peternakan, Universitas Brawijaya, Malang. Semen yang digunakan dalam penelitian memiliki persyaratan minimal motilitas massa ++ dan motilitas minimal 70\%. Media pengencer yang digunakan adalah Tris Kuning Telur diperoleh dari Balai Besar Inseminasi Buatan Singosari (BBIB Singosari). Ditambahkan sebanyak $2 \mathrm{ml}$ ke dalam larutan sperma. Ekstrak daun kemangi dibuat sendiri menggunakan daun kemangi yang didapatkan dari pasar tradisional Blimbing dan Karang Ploso, Kabupaten Malang.

\section{Metode penelitian}

Metode penelitian menggunakan pola Rancangan Acal Lengkap (RAL) dengan 4 perlakuan dan 10 kali ulangan. Perlakuan yang digunakan adalah penambahan konsentrasi ekstrak daun kemangi yang berbeda yaitu:

$$
\begin{aligned}
& \mathrm{P} 0=0 \% \text { Ekstrak daun kemangi } \\
& \mathrm{P} 1=1 \%(0,02 \mathrm{ml}) \text { Ekstrak daun kemangi } \\
& \mathrm{P} 2=2 \%(0,04 \mathrm{ml}) \text { Ekstrak daun kemangi } \\
& \mathrm{P} 3=3 \%(0,06 \mathrm{ml}) \text { Ekstrak daun kemangi. }
\end{aligned}
$$

\section{Pembuatan ekstrak daun kemangi}

Pembuatan ekstrak daun kemangi menggunakan metode maserasi. Daun kemangi dipisahkan antara daun dan batang lalu dicuci bersih. Dikeringkan daun kemangi dengan cara diangin-anginkan, setelah kering daun di grinder sampai menjadi serbuk. Sebanyak 160 gram serbuk daun kemangi dimasukkan ke dalam wadah, kemudian direndam dengan larutan aseton $70 \%$, sebanyak $800 \mathrm{ml}$, ditutup dengan alumunium foil dan dibiarkan selama 5 hari sambil sesekali diaduk. Setelah 5 hari, sampel disaring menggunakan kertas saring menghasilkan filtrate 1 dan residu 1 . Residu yang ada kemudian ditambah dengan larutan aseton $70 \%$ sebanyak $480 \mathrm{ml}$, ditutup dengan alumunium foil dan dibiarkan selama 2 hari sanbil sesekali diaduk. Setelah 2 hari, sampel tersebut disaring menggunakan kertas saring menghasilkan filtrate 2 dan residu 2. Filtrate 1 dan 2 dicampur menjadi satu, lalu disentrifugasi selama 10 menit dengan kecepatan $1500 \mathrm{rpm}$. Setelah itu dipisahkan filtrat dan residu, lalu filtrat dievaporasi menggunakan rotatory evaporator, sehingga diperoleh ekstrak daun kemangi. Ekstrak daun kemangi yang dihasilkan diinaktivasi menggunakan oven dengan suhu $60^{\circ} \mathrm{C}$ selama 15 menit. Ekstrak disimpan dalam wadah gelas tertutup sebelum digunakan dalam pengujian. 


\section{Penampungan semen}

Penampungan semen dilakukan pada pagi hari pukul 06.00-07.00 WIB dengan frekuensi penampungan 4 kali dalam seminggu. Penampungan semen dilakukan di Laboratorium Lapang Sumber Sekar, Kecamatan Dau Kabupaten Malang. Metode penampungan semen menggunakan vagina buatan. Kambing betina disiapkan dan dimasukkan ke dalam kandang jepit. Sebelum penampungan, kambing pejantan dibiarkan melakukan false mounting sebanyak 2 kali dan pada mounting ke 3 bagian preputeum pejantan dipegang guna mengarahkan penis ke lubang vagina buatan. Setelah semen tertampung segera dievaluasi motilitas massa dan individu mikroskopis.

\section{Pengamatan semen segar}

a. Warna, pemeriksaan warna semen dilakukan dengan melihat semen yang ada pada tabung penampungan secara langsung. Warna semen meliputi putih, putih susu, putih kekuningan dan krem

b. Konsistensi, dilakukan dengan melihat derajat kekentalan. Penilaian konsistensi meliputi encer, sedang dan kental

c. Volume, membaca skala yang terdapat pada tabung penampunngan

d. $\mathrm{pH}$, untuk mengetahui $\mathrm{pH}$ semen, dilakukan dengan meneteskan semen pada kertas lakmus sebanyak satu tetes. Uji $\mathrm{pH}$ semen menggunakan $\mathrm{pH}$ paper, $\mathrm{pH}$ normal semen biasanya berkisar antara 6,2-6,8

e. Konsentrasi, uji konsentrasi semen dilakukan dengan menggunakan haemocytometer dengan ruang hitung Neubauer dimana konsentrasi diperoleh dengan menghitung jumlah spermatozoa yang terdapat dalam kotak kecil sebanyak 5 buah lalu dikalikan 107

f. Motilitas, evaluasi motilitas massa menggunakan mikroskop dengan perbesaran 100x, dan motilitas individu dengam perbesaran $400 \mathrm{x}$

g. Viabilitas, pemeriksaan spermatozoa yang hidup dengan cara membuat preparat ulas. Perhitungan viabilitas dilakukan dengan menggunakan miskroskop pembesaran 400x. Spermatozoa dikatakan hidup apabila bagian kepala spermatozoa tidak menyerap warna, sedangkan spermatozoa dikatakan mati apabila bagian kepala spermatozoa menyerap warna dari eosin

h. Abnormalitas, dihitung dari spermatozoa yang memiliki abnormalitas primer maupun sekunder. Perhitungan abnormalitas spermatozoa dilakukan dengan menggunakan preparat ulas dan diperiksa dibawah mikroskop dengan perbesaran 400x.

\section{Pengenceran semen}

Setelah dilakukan evaluasi terhadap kualitas semen segar, semen dibagi ke dalam empat perlakuan pengencer Tris Kuning Telur yang telah ditambahkan ekstrak daun kemangi. Semen diencerkan sesuai dengan perlakuan, volume pengencer yang digunakan diperoleh dari perhitungan jumlah konsentrasi semen segar. Semen yang telah diencerkan disimpan pada suhu ruang dan di evaluasi kualitas semen meliputi motilitas individu, viabilitas dan abnormalitas pada penyimpanan jam ke $0,1,2$ dan 3 . 


\section{HASIL DAN PEMBAHASAN}

\section{Kualitas semen segar}

Rataan kualitas semen segar berdasarkan penelitian yang telah dilakukan dapat dilihat pada Tabel 1 .

Tabel 1. Kualitas semen segar kambing Boer

\begin{tabular}{ll}
\hline \hline Parameter & Rataan \\
\hline Volume $(\mathrm{ml})$ & $1,33 \pm 0,2$ \\
Warna & Putih Kekuningan \\
Konsistensi & Kental \\
$\mathrm{pH}$ & 7 \\
Bau & Khas \\
Motilitas massa & +++ \\
Motilitas individu $(\%)$ & $78,33 \pm 3,54$ \\
Viabilitas $(\%)$ & $83,09 \pm 3,98$ \\
Abnormalitas $(\%)$ & $5,14 \pm 2,69$ \\
Konsentrasi $\left(10^{6} / \mathrm{ml}\right)$ & $3749 \pm 1439,96$ \\
\hline
\end{tabular}

Hasil penelitian menunjukkan bahwa volume semen segar kambing Boer adalah $1,33 \pm 0,2 \mathrm{ml} /$ ejakulasi. Beberapa laporan menunjukkan bahwa volume semen kambing Boer yaitu 0,94 $\pm 0,26 \mathrm{ml} /$ ejakulasi (Istanti et al. 2017) dan 1,3 $\pm 0,24 \mathrm{ml} /$ ejakulasi (Suyadi et al. 2012). Susilawati (2011) menambahkan bahwa volume yang diejakulasikan dipengaruhi oleh umur pejantan, kondisi fisik, musim, ketrampilan, kolektor dan frekuensi penampungan. Aisah et al. (2017) menambahkan bahwa volume semen, konsentrasi dan motilitas spermatozoa dapat dipengaruhi oleh curah hujan, curah hujan yang tinggi dan intensitas cahaya yang rendah dapat menghambat produksi hormone FSH sehingga menghambat proses spermatogenesis dalam testis.

Data hasil penelitian menunjukkan bahwa warna semen kambing Boer adalah putih kekuningan. Lestari et al. (2014) menyatakan bahwa warna semen kambing Boer adalah putih kekuningan, warna krem pada semen masih tergolong normal. Hal ini disebabkan adanya riboflavin dari sekresi kelenjar vesikularis serta semen segar yang memiliki jumlah spermatozoa banyak, yang akan mengakibatkan semen lebih kental dan warna lebih pekat. Warna semen dapat dipengaruhi oleh konsistensi dan konsentrasi spermatozoa, semakin kental konsistensi dan semakin banyak konsentrasi menyebabkan warna dari semen semakin pekat. Suyadi et al. (2012) menambahkan bahwa warna, konsistensi dan konsentrasi memiliki hubungan yang erat, apabila semen memiliki konsistensi yang encer, maka warna yang ditampilkan akan semakin pucat dan konsentrasi spermatozoa semakin rendah. Warna merah muda pada semen mengindikasikan adanya pendarahan pada penis saat penampungan, sedangkan warna abu-abu atau kecoklatan mengindikasikan terdapatnya infeksi pada saluran reproduksi jantan (Susilawati 2011). Semen pada penelitian ini memiliki bau yang khas, Suyadi et al. (2012) menambahkan bahwa semen dalam keadaan normal umumnya memiliki bau khas dari hewan tersebut. 
Konsistensi semen segar kambing Boer hasil penelitian adalah kental. Konsistensi sendiri merupakan salah satu sifat semen yang memiliki hubungan dengan konsentrsi semen didalamnya (Munazaroh et al. 2013). Konsistensi dipengaruhi oleh perbandingan antara plasma semen dengan spermatozoa. Suyadi et al. (2012) menambahkan bahwa semen dengan konsistensi kental mempunyai konsentrasi spermatozoa lebih tinggi dibandingkan dengan semen yang encer. Susilawati (2011) menyatakan penilaian semen encer $(<1000.106$ spermatozoa/ml semen), sedang (1000.106-1500.106 spermatozoa/ml semen) dan pekat (>1500.106 spermatozoa/ml semen).

Hasil penelitian menunjukkan bahwa derajat keasaman $(\mathrm{pH})$ dari semen segar kambing Boer adalah 7. Beberapa laporan menunjukkan $\mathrm{pH}$ semen segar kambing memiliki rata-rata 6,3 sampai 6,5 (Dethan et al. 2010), Susilawati (2011) menambahkan bahwa pada umumnya $\mathrm{pH}$ normal semen berkisar antara 6,2-6,8. $\mathrm{pH} 7$ pada semen yang diteliti termasuk pada kisaran netral. Derajat keasaman $(\mathrm{pH})$ memiliki peranan penting dalam spermatozoa. Meningkatnya derajat keasaman pengencer akan mengganggu proses dalam sel spermatozoa, sehingga suplai berupa adenosine trifosfat (ATP) berkurang yang menyebabkan menurunnya motilitas spermatozoa dan berakibat pada turunnya daya hidup spermatozoa (Rizal et al. 2015).

Data hasil penelitian menunjukkan bahwa motilitas semen segar kambing Boer memiliki nilai 3+ ditandai dengan pergerakan adanya gelombang awan pekat yang bergerak cepat dan progresif. Kriteria penilaian gerak massa spermatozoa antara lain, a) sangat baik (+++) terlihat adanya gelombang besar, banyak, gelap, tebal, dan aktif seperti gumpalan awan hitam dekat waktu hujan yang bergerak cepat dan berpindah-pindah tempat, b) baik (++) bila terdapa gelombang-gelombang kecil tipis, jarang, kurang kelas dan bergerak lamban. C) kurang baik (+), jika tidak terilah gelombang melainkan gerakan-gerakan individu aktif progresif dan d) buruk (0), bila hanya sedikit ada gerakangerakan individual (Susilawati 2011). Motilitas massa merupakan parameter keaktifan spermatozoa sebagai indikator tingkat persentase spermatozoa hidup dan aktif dalam semen (Suyadi et al. 2012). Hal ini mengindikasikan bahwa semen segar kambing Boer hasil pengamatan mempunyai pergerakan progresif yang tinggi.

Motilitas individu merupakan salah satu syarat penilaian kualias semen. Persentase spermatozoa yang motil (bergerak progresif) dapat digunakan sebagai ukuran kesanggupan untuk membuahi ovum (Lestari et al. 2014). Rataan persentse motilitas individu semen segar hasil penelitan menunjukkan nilai 78,33 $\pm 3,54 \%$, hasil ini lebih tinggi dibandingkan laporan Munazaroh et al. (2013) motilitas individu semen segar kambing Boer adalah 73,33 $55,77 \%$. Kualitas semen masih dapat dikatakan baik apabila memiliki motilitas lebih dari 50\% (Rahayu et al. 2014). Persentase rataan motilitas individu semen segar tersebut telah memenuhi Standar Nasional Indonesia (SNI) bahwa minimal motilitas individu semen segar untuk diproses lebih lanjut adalah $70 \%$.

Viabilitas merupakan salah satu indicator penentu kualitas semen, penilaian persentase viabilitas spermatozoa dapat menggunakan pewarnaan eosin negrosin. Rataan persentase viabilitas pada penelitian ini adalah $83,09 \pm 3,98 \%$. Viabilitas ini lebih rendah dibandingkan semen segar kambing Boer pada penelitian lain yaitu 93,17 $\pm 0,58 \%$ (Rahayu et al. 2014). Perbedaan nilai ini dapat disebabkan faktor umur ternak, pakan, lingkungan dan variasi individu ternak. Semen normal memiliki persentase hidup minimal $50 \%$.

Rataan persentase abnormalitas semen segar kambing Boer berdasarkan data hasil penelitian sebesar 5,14 $\pm 2,69 \%$. Hasil ini lebih tinggi dibandingkan dengan laporan Lestari et al. (2014) bahwa rataan abnormalitas semen segar kambing Boer sebesar $3,57 \pm 0,55 \%$. Nilai abnormal ini masih berada dalam kisaran normal. Abnormalitas 
terbagi menjadi dua yaitu primer dan sekunder. Abnormalitas primer terjadi pada proses spermatogenesis yang meliputi kepala terlalu kecil, kepala terlalu besar, kepala pipih dan ekor ganda, sedangkan abnormalitas sekunder terjadi setelah semen ditampung yang meliputi kepala putus, ekor putus, kepala tanpa ekor dan ekor tanpa kepala.

Konsentrasi memiliki hubungan yang erat dengan konsistensi serta warna semen segar. Konsentrasi semen segar kambing Boer dalam penelitian ini memiliki rataan $3749 \pm 1439,96$ x 106/ml. Nilai konsentrasi yang semakin tinggi berdampak pada konsistensi yang semakin kental.

\section{Pengaruh penambahan ekstrak daun kemangi terhadap motilitas spermatozoa selama penyimpanan suhu ruang}

Penyimpanan semen bertujuan untuk mengoptimalkan jangka waktu penggunaan semen pejantan unggu dan penyebaran bibit unggul di tempat yang membutuhkan. Penyimpanan semen dalam waktu yang lama dapat menurunkan motilitas spermatozoa. Motilitas individu spermatozoa merupakan salah satu faktor kualitas semen yang diperhatikan dalam pelaksanaan Inseminasi Buatan. Hasil pengamatan persentase motilitas individu spermatozoa kambing Boer yang telah diencerkan dengan pengencer Tris Kuning Telur pada berbagai level ekstrak daun kemangi (EDK) dapat dilihat pada Tabel 2.

Tabel 2. Rataan persentase motilitas individu sperma kambing Boer dengan penambahan ekstrak daun kemangi selama penyimpanan suhu ruang

\begin{tabular}{lcccc}
\hline \hline \multirow{2}{*}{ Perlakuan } & \multicolumn{4}{c}{ Pengamatan } \\
\cline { 2 - 5 } & Jam 0 & Jam 1 & Jam 2 & Jam 3 \\
\hline P0 $(0 \%)$ & $71 \pm 5,15$ & $61 \pm 5,68$ & $53 \pm 5,87$ & $42 \pm 4,83$ \\
P1 $(1 \%)$ & $71 \pm 3,94$ & $61 \pm 6,69$ & $52 \pm 5,87$ & $41,5 \pm 4,5$ \\
P2 (2\%) & $71 \pm 4,74$ & $63 \pm 5,37$ & $55 \pm 6,67$ & $41 \pm 6,15$ \\
P3 (3\%) & $73 \pm 4,83$ & $65 \pm 4,97$ & $55 \pm 5,57$ & $44 \pm 6,43$ \\
\hline
\end{tabular}

Hasil penelitian menunjukkan bahwa perlakuan penambahan ekstrak daun kemangi tidak berpengaruh $(\mathrm{P}>0,05)$ terhadap motilitas spermatozoa selama penyimpanan suhu ruang pada jam ke $0,1,2$ dan 3 dari semua perlakukan. Hasil penelitian Nurkholis \& Prasetyo (2014) menunjukkan bahwa penambahan antioksidan dari ekstrak edamame tidak berpengaruh nyata terhadap motilitas spermatozoa kambing peranakan etawah selama proses penyimpanan pada suhu kamar, hal ini diduga karena peluang kontak antara semen dengan udara cukup besar. Menurut Hammerstedt (1993), reaksi samping metabolisme aerob akan menghasilkan anion superoksida yang dapat menyebabkan kerusakan sel apabila bereaksi dengan oksigen. Sehingga, antioksidan yang ada pada ekstrak kemangi kurang dapat berfungsi sebagai superoksida yang dapat menghilangkan anion superoksida dan meminimalkan kerusakan peroksidatif. 


\section{Pengaruh penambahan ekstrak daun kemangi terhadap viabilitas spermatozoa selama penyimpanan suhu ruang}

Viabilitas merupakan salah satu indikator penentu kualitas semen, penilaian persentase viabilitas spermatozoa dapat menggunakan pewarnaan eosin negrosin. Spermatozoa yang hidup akan berwarna terang, sedangkan spermatozoa yang mati akan berwarna ungu karena menyerap eosin negrosin. Spermatozoa yang mati mengalami kerusakan membran sel sehingga menyerap zat warna eosin yang diberikan. Hasil analisis statistik menunjukkan bahwa penambahan ekstrak daun kemangi tidak berpengaruh $(\mathrm{P}>0,05)$ terhadap viabilitas spermatozoa.

Tabel 3. Rataan persentase viabilitas spermatozoa kambing boer dengan penambahan ekstrak daun kemangi selama penyimpanan suhu ruang

\begin{tabular}{lcccc}
\hline \hline \multirow{2}{*}{ Perlakuan } & \multicolumn{4}{c}{ Pengamatan } \\
\cline { 2 - 5 } & Jam 0 & Jam 1 & Jam 2 & Jam 3 \\
\hline P0 (0\%) & $84,0 \pm 7,18$ & $80,2 \pm 6,38$ & $78,1 \pm 6,77$ & $65 \pm 11,15$ \\
P1 (1\%) & $86,2 \pm 6,18$ & $81,4 \pm 6,97$ & $77,2 \pm 6,16$ & $72,3 \pm 8,44$ \\
P2 (2\%) & $85,3 \pm 8,18$ & $81,9 \pm 7,68$ & $77,3 \pm 8,95$ & $73,2 \pm 7,12$ \\
P3 (3\%) & $87,4 \pm 3,03$ & $82,5 \pm 2,57$ & $78,3 \pm 4,48$ & $74,5 \pm 5,74$ \\
\hline
\end{tabular}

Hasil penelitian Nurkholis \& Prasetyo (2014) menunjukkan bahwa penambahan antioksidan dari ekstrak edamame tidak berpengaruh nyata terhadap motilitas spermatozoa kambing peranakan etawah. Penambahan ekstrak daun kemangi yang tidak memberikan pengaruh terhadap viabilitas spermatozoa kambing Boer diduga disebabkan oleh kandungan flavonoid dalam ekstrak daun kemangi yang kurang optimal untuk mempertahankan kualitas sperma. Musfirah et al. (2016) menyatakan bahwa flavonoid berkhasiat sebagai antioksidan mampu mempertahankan kualitas sperma. Flavonoid mampu mempertahankan kualitas sperma dengan mempertahankan motilitas spermatozoa sehingga meningkatkan viabilitas sperma dan meningkatkan jumlah sperma (Louis et al. 2019).

Penurunan nilai viabilitas disebabkan karena spermatozoa kehabisan energi selama masa penyimpanan. Munazaroh et al. (2013) berpendapat bahwa terjadinya penurunan viabilitas selama proses penyimpanan dapat disebabkan karena perlakuan fisik saat perlakuan yang menyebabkan kematian.

\section{Pengaruh penambahan ekstrak daun kemangi terhadap abnormalitas spermatozoa selama penyimpanan suhu ruang}

Abnormalitas merupakan kelainan bentuk yang dialami oleh spermatozoa. Hasil rataan persentase abnormalitas spermatozoa kambing Boer dengan penambahan ekstrak daun kemangi dapat dilihat pada Tabel 4. 
Tabel 4. Rataan persentase abnormalitas spermatozoa kambing Boer dengan penambahan ekstrak daun kemangi selama penyimpanan suhu ruang

\begin{tabular}{lcccc}
\hline \hline \multirow{2}{*}{ Perlakuan } & \multicolumn{4}{c}{ Pengamatan } \\
\cline { 2 - 5 } & Jam 0 & Jam 1 & Jam 2 & Jam 3 \\
\hline P0 $(0 \%)$ & $5,33 \pm 1,53$ & $6,52 \pm 1,38^{\mathrm{c}}$ & $7,99 \pm 1,82^{\mathrm{b}}$ & $11,56 \pm 4,03^{\mathrm{b}}$ \\
P1 $(1 \%)$ & $4,45 \pm 1,88$ & $5,11 \pm 1,32^{\mathrm{b}}$ & $5,78 \pm 0,90^{\mathrm{a}}$ & $7,15 \pm 1,42^{\mathrm{a}}$ \\
P2 (2\%) & $4,52 \pm 2,07$ & $4,31 \pm 1,59^{\mathrm{a}}$ & $6,21 \pm 0,96^{\mathrm{a}}$ & $7,54 \pm 1,15^{\mathrm{a}}$ \\
P3 (3\%) & $3,90 \pm 0,69$ & $4,46 \pm 1,02^{\mathrm{a}}$ & $6,63 \pm 1,30^{\mathrm{a}}$ & $7,26 \pm 1,21^{\mathrm{a}}$ \\
\hline
\end{tabular}

Notasi yang berbeda pada jam ke 1, 2 dan 3 menunjukkan adanya perbedaan yang nyata $(\mathrm{P}<0,05)$

Berdasarkan hasil analisis statistik menunjukkan bahwa penambahan ekstrak daun kemangi berpengaruh $(\mathrm{P}<0,05)$ terhadap abnormalitas spermatozoa pada jam ke 1,2 dan 3. Abnormalitas terendah terdapat pada jam ke 0 yaitu pada perlakuan P3 (3,90\%). Pada penyimpanan jam ke 2 dan jam ke 3, nilai abnormalitas pada setiap perlakukan penambahan ekstrak daun kemangi lebih rendah dibandingkan tanpa penambahan ekstrak. Kandungan antioksidan flavonoid dalam ekstrak daun kemangi mampu mempertahankan nilai abnormalitas. Rizal \& Herdis (2010) menambahkan bahwa penambahan antioksidan mampu menghentikan reaksi yang ditimbulkan oleh radikal bebas. Siswandoko (2017) menambahkan bahwa pemberian antioksidan dengan dosis yang tepat memberikan hasil maksimal untuk mencegah dan mengurangi reaksi peroksida lipid akibat aktivitas radikal bebas pada membran plasma spermatozoa, dimana bagian tersebut kaya akan asam lemak tak jenuh sehingga rentan terhadap reaksi peroksida lipid. Berkurangnya reaksi peroksidasi lipid akan berdampak pada rendahnya nilai abnormalitas spermatozoa. Kandungan flavonoid dalam ekstrak daun kemangi berguna sebagai antioksidan yang akan menetralkan radikal bebas sehingga mencegah kerusakan pada spermatozoa (Khaki et al. 2011).

Peningkatan nilai abnormalitas selama penyimpanan dapat dipengaruhi oleh spermatogenesis ternak dan juga perlakukan setelah ejakulasi. Menurut Wiratri et al. (2013) abnormalitas mengalami peningkatan pada tiap jam, hal ini dapat dipengaruhi oleh spermatogenesis dari ternak tersebut dan juga perlakuan setelah ejakulasi, seperti penanganan semen segar, pencampuran semen dengan pengencer dan saat pembuatan ulasan. Selain itu perubahan suhu dapat menyebabkan perubahan permeabilitas membranesel dinding spermatozoa dan mengakibatkan disharmonisme, pemecahan membran, dan pengeluaran enzim. Kondisi ini dapat menyebabkan peningkatan abnormalitas spermatozoa. Abnormalitas spermatozoa akan mengalami peningkatan yang disebabkan oleh spermatogenesis dari ternak tersebut dan perlakuan setiap penampungan semen segar, pencampuran semen dengan pengencer dan saat pembuatan ulasan. Faktor lain yang mempengaruhi peningkatan abnormalitas adalah tindakan kurang hati-hati pada saat perlakuan, panas, gangguan nutrisi dan pengaruh fisik dimana spermatozoa saling bergesekan satu sama lain sehingga menyebabkan abnormalitas sekaligus kematian (Munazaroh et al. 2013).

Hasil pengamatan menunjukkan bahwa pada jam ke 3 nilai abnormalitas spermatozoa kambing Boer berada pada kisaran 7,15-11,56\%. Nilai ini masih dapat digunakan untuk inseminasi buatan. Kusumawati et al. (2017) menyatakan bahwa standar persentase abnormalitas spermatozoa kambing yang layak digunakan untuk IB tidak lebih 
dari $15 \%$. Sedangkan menurut Susilawati (2011) nilai abnormalitas yang dapat digunakan lebih lanjut untuk IB adalah kurang dari $20 \%$ morfologi spermatozoa abnormal.

\section{KESIMPULAN}

Penambahan ekstrak daun kemangi (Ocimum sanctum) ke dalam pengencer belum mampu memberikan pengaruh terhadap motilitas individu dan viabilitas semen kambing boer selama penyimpanan suhu ruang. Ekstrak daun kemangi mampu mengurangi abnormalitas semen kambing Boer selama penyimpanan suhu ruang hingga 3 jam.

\section{DAFTAR PUSTAKA}

Aisah S, Isnaini N, Wahyuningsih S. 2017. Kualitas semen segar dan recovery rate sapi bali pada musim yang berbeda. J Ilmu-Ilmu Peternakan. 27:63-79.

Dethan AA, Kustono, Hartadi H. 2010. Kualitas dan kuantitas sperma kambing bligon jantan yang diberi pakan rumput gajah dengan suplementasi tepung darah. Buletin Peternakan. 34:145-153.

Erviana L, Malik A, Ahmad N. 2012. Uji aktivitas antiradikal bebas ekstrak etanol daun kemangi (ocimum basilicum l.) dengan menggunakan metode dpph. J Fitofarmaka Indonesia. 3:164-168.

Hammerstedt RH. 1993. Maintenance of bioenergic balance in sperm and prevention of lipid peroxydation. Reprod Fertil Dev. 5:675-690.

Hayati A, Mangkoewidjojo S, Hinting A, Moeljopawiro S. 2006. Hubungan kadar mda sperma dengan integritas membran spermatozoa tikus (Rattus norvegicus) setelah pemaparan 2-methoxyethanol. Berk Penel Hayati. 11:151-154.

Indriani, Susilawati T, Wahjuningsih S. 2013. Daya hidup spermatozoa sapi Limousin yang dipreservasi dengan metode water jacket dan free water jacket. J Veteriner. 14:379-386.

Istanty AS, Salim MA, Isnaini N, Susilawati T. 2017. Pengaruh penggantian bovine serum albumin (bsa) dengan putih telur dalam pengencer dasar CEP-2 terhadap kualitas semen kambing Boer pada simpan dingin. J Ternak Tropika. 18:1-9.

Khaki A, Fathiazad F, Nouri M, Amir AK. 2011. Effect of Ocimum basilicum on apoptosis in testis if rats after exposure ti electromagnetic field. Afr J Pharm Parmacol. 5:1534-1537.

Kusuma W. 2010. Efek ekstrak daun kemangi (Ocimum sanctum 1.) terhadap kerusakan hepatosit mencit akibat minyak sawit dengan pemanasan berulang [Skripsi]. [Surakarta (Indonesia)]: Universitas Sebelas Maret.

Kusumawati DE, Utomo KN, Krisnaningsih AJN, Syam R. 2017. Kualitas semen kambing kacang dengan lama simpan yang berbeda pada suhu ruang menggunakan pengencer tris aminomethan kuning telur. JITRO. 4:42-51.

Lestari TPS, Ihsan MN, Isnaini N. 2014. Pengaruh waktu simpan semen segar dengan pengencer andromed pada suhu ruang terhadap kualitas semen kambing boer. J Ternak Tropika. 15:43-50.

Louis SL, Salni, Sri N. 2019. Pengaruh pemberian fraksi daun kemangi (ocimum ameriacnum, 1.) terhadap berat, diameter, tebal epitel epididimis, motilitas dan viabilitas spermatozoa tikus putih jantan (rattus norvegicus). J Kesehatan. 10:25-33.

Munazaroh AM, Wahyuningsih S, Gatot C. 2013. Uji kualitas spermatozoa kambing boer hasil pembekuan menggunakan $\mathrm{mr}$. frosty ${ }^{\circledR}$ pada tingkat pengenceran andromed ${ }^{\circledR}$ berbeda. J Ternak Tropika. 14:63-71. 
Musfirah Y, Bachri MS, Laela HN. 2016. Potensi ekstrak etanol 70\% akar salunang balum (lavanga sarmentosa blume kurz) terhadap kualitas dan viabilitas sperma mencit. Pharmaciana. 6:131-138.

Nurkholis, Prasetyo B. 2014. Minimalisasi kerusakan spermatozoa kambing peranakan etawah akibat radikal bebas selama periode cryopreservation dengan penambahan a tokoferol dari ekstrak limbah edamame dalam skim milk dilution. J Ilmiah Inovasi. 14:163-170.

Rahayu W, Pramana AWM, Gatot C. 2014. Kualitas semen segar kambing boer pada temperatur penyimpanan $4{ }^{\circ} \mathrm{C}$ dengan menggunakan pengencer sitrat dan suplementasi susu kedelai bubuk. J Biotropika. 2:55-60.

Rizal, Herdis. 2010. Peranan antioksidan dalam meningkatkan kualitas semen beku. Wartazoa. 20:139-145.

Rizal M, Herdis, Nasrullah, Riyadhi M, Sangadji I, Yulnawati. 2015. Kriopreservasi semen domba garut dengan pengencer tris yang disuplementasi ethylene diamine tetraacetic acid. J Veteriner. 16:249-255.

Setiono N, Suharyati S, Santosa PE. 2015. Kualitas semen beku sapi Brahman dengan dosis krioprotektan gliserol yang berbeda dalam bahan pengencer tris sitrat kuning telur. $\mathbf{J}$ Ilmiah Peternakan. 3:61-69.

Siswandoko B, Zaenab S, Husamah. 2017. Penambahan ektrak kulit buah naga ke dalam pengencer tris kuning telur untuk meningkatkan kualitas semen beku kambing peranakan ettawa. Scripta Biologica. 4:247-251.

Susilawati T. 2011. Spermatology. Malang (Indonesia): UB Press.

Suyadi, Rachmawati A, Iswanto N. 2012. Effect of $\alpha$-tocopherol in tris-aminomethane-egg yolk on the semen quality during cold storage in boer goats. J Ilmu-ilmu Peternakan. 22:1-8.

Wiratri VDB, Susilawati T, Wahjuningsih S. 2015. Kualitas semen sapi limousin pada pengencer yang berbeda selama pendinginan. J Ternak Tropika. 15:13-20. 